\title{
Development of coagulant synthesis byproducts from cengar clay as adsorbent in post-coagulation peat water treatment
}

\author{
Muhdarina Muhdarina ${ }^{1 *}$, Sasmi Nopiyani ${ }^{1}$, Syaiful Bahri $^{2}$, Amilia Linggawati ${ }^{1}$, and Peppy Helza \\ Yanti $^{1}$ \\ ${ }^{1}$ Material Science Research Laboratorium Department of Chemistry, Universitas Riau, Pekanbaru, \\ Indonesia \\ ${ }^{2}$ Chemical Reaction Engineering Laboratory, Department of Chemical Engineering, Universitas Riau, \\ Pekanbaru, Indonesia
}

\begin{abstract}
Cengar clay was used as a precursor for liquid coagulant and adsorbent. It was calcined at $700^{\circ} \mathrm{C}$ for 1 hour followed by extracting with 0.2 moles $\mathrm{H}_{2} \mathrm{SO}_{4}$ at 80 and $100^{\circ} \mathrm{C}$ for 2 hours respectively. The main products are liquid coagulant of $\mathrm{LC}_{1(80-2)}$ and $\mathrm{LC}_{1(100-2)}$ which applied to coagulate the peat water. The liquid coagulants were characterized for $\mathrm{pH}$ and cation contents. And then after coagulation, peat water were adsorbed by using each extraction byproducts of liquid coagulant include $\operatorname{LCA}_{1(80-2)}$ and $\mathrm{LCA}_{1(100-2)}$ having adsorbent-peat water ratio 0.5:100 and 1:100 (w/v). Minerals characteristic of adsorbents were characterized using X-ray diffraction method. The several peat water parameters were analyzed for $\mathrm{pH}$, color, turbidity, and organic substances. The results achieved that liquid coagulants were containing bivalent cation $(\mathrm{Ca}$ and $\mathrm{Mg}$ ) far more than trivalent cation ( $\mathrm{Al}$ and $\mathrm{Fe})$ and $\mathrm{pH}$ 7-8. On the other hand, the adsorbent has found of kaolinite, montmorillonite, muscovite and calcite minerals. The liquid coagulant has not been able to improve the overall parameters analyzed. However, the $\mathrm{LC}_{1(80-2)}$ coagulant achieved only removal efficiency of color $12.47 \%$, turbidity $17.59 \%$ and organic substances $2.55 \%$ respectively. Meanwhile, the most effective adsorbent for post-coagulation peat water was achieved by $\operatorname{LCA}_{1(80-2)}$ on 1:100 ratio that increases the water $\mathrm{pH}$ becomes neutral, removal efficiency of color $96.57 \%$, turbidity $98.03 \%$ and organic substances $81.55 \%$, respectively. Therefore, the adsorbent performance is much better than the coagulant in peat water treatment. As a conclusion, the adsorption step can cope up with the bad condition of post-coagulation of peat water.
\end{abstract}

\section{Introduction}

Surface and groundwater, and industrial or household wastewater contain many different types of metallic, inorganic, and organic compounds that are hazardous to a human being,

\footnotetext{
${ }^{1}$ Corresponding author: muhdarina.m@lecturer.unri.ac.id
} 
animals, and plants. By 2050, global population is expected to reach up to 9.3 billion and the world may be under great freshwater scarcity [1]. Therefore, the removal of toxic organic pollutants from water is inevitably essential in this present scenario.

In the recent past, various types of clay have been increasingly used in several remediation and pollution control processes. This usage is being inexpensive and abundant in Indonesia, especially in Riau Province. Natural mineral clays possessed specific surface chemical properties, e.g., cation exchange capacity, and adsorptive affinity for some organic and inorganic compounds, which have led to an investigation on the potential use of clays as an adsorbent for treating heavy metal, and inorganic pollutants, or as coagulant agents [2, 3].

In this report, it has been investigated the application of clay from Riau Province. Clay originated from Cengar of Kuantan Singingi has been reported as coagulant due to its contained $\mathrm{Al}$ and $\mathrm{Fe} 14.37 \%$ and $1.01 \%$, respectively [4]. The previous experiment [5] has been revealed that calcinated Cengar clay at $700^{\circ} \mathrm{C}$ for 3 hours and extracted by $\mathrm{H}_{2} \mathrm{SO}_{4} 0.2$ moles at $100^{\circ} \mathrm{C}$ for 2 hours appeared to repair some of peat water parameters. It was met Permenkes No.416/Menkes/PER/IX/1990, such as several parameters of odorless, having pH 8.02, turbidity 4 NTU, Total Dissolved Solid (TDS) $278 \mathrm{mg} / \mathrm{L}$, and Total Suspended Solid (TSS) $7 \mathrm{mg} / \mathrm{L}$. On the other hand, the advanced process is still needed to repair its parameters of color and organic substances.

Liquid coagulant was produced after extraction process of clay as precursor using $\mathrm{H}_{2} \mathrm{SO}_{4}$, and there was residual solid as minor product found from this experiment. The residual solid would become waste if it disposed to the environment. Even though this residue is thought still have an adsorption ability, so it can be used as an adsorbent postcoagulation peat water. Adsorption process will remove the soluble and insoluble organic pollutants. The removal capacity ranging from 80 to $99 \%$ was reported [6]. The residual solid adsorbent is expected to remediate color and organic substances of post-coagulation peat water. There were many studies revealed elsewhere using clay as a coagulant [7-11] or an adsorbent $[12,13]$, but herein, it was reported the economic strategy for peat water treatment with combine both of coagulation-adsorption process.

\section{Materials and methods}

The materials used were as follow; natural clay (originated from Kuantan riverside, Cengar Village, Kuantan Singingi District, Riau Province), peat water (collected from Rimbo Panjang, near of Pekanbaru), $98 \% \mathrm{H}_{2} \mathrm{SO}_{4}$ (E-Merck), $\mathrm{KMnO}_{4}$ (E-Merck), $\mathrm{H}_{2} \mathrm{C}_{2} \mathrm{O}_{4} \cdot 2 \mathrm{H}_{2} \mathrm{O}$ (E-Merck), Whatman filter paper No. 42, aluminum foil, buffer solution $\mathrm{pH} 4,7$ and 9.

Natural clay washed with aquadest, dried, and then crushed to have powder have a desired particle size range of $100 \leq \mathrm{x} \leq 200$ mesh. The clay powder is dried $105^{\circ} \mathrm{C}$ in an oven by gravimetry method. Furthermore, the clay was calcined in a furnace Nebertherm $\mathrm{L} 31 \mathrm{R}$ at $700^{\circ} \mathrm{C}$ for 1 hour. And then a $30 \mathrm{~g}$ of the calcined clay was extracted using $360 \mathrm{~mL}$ $\mathrm{H}_{2} \mathrm{SO}_{4} 0.2$ moles. And then heating over an hot plate stirrer REXIM RSH-1DR L120 having a stirring speed of $700 \mathrm{rpm}$ at $80^{\circ} \mathrm{C}\left(\mathrm{LC}_{1(80-2)}\right)$ and $100^{\circ} \mathrm{C}\left(\mathrm{LC}_{1(100-2)}\right)$ for 2 hours. The mixture was allowed for \pm 24 hours. Liquid coagulant was withdrawn using pipette from the top inch of the supernatant. Liquid coagulants are measured of acidity by $\mathrm{pH}$ meter pen pH-009(I), and the content of $\mathrm{Al}^{3+}, \mathrm{Fe}^{3+}, \mathrm{Na}^{+}, \mathrm{K}^{+}, \mathrm{Ca}^{2+}$, and $\mathrm{Mg}^{2+}$ cations using ICP-EOS Perkin Elmer type Optima 8000. The solid precipitate (LCA) was filtered using Whatman No. 42. LCA is given a symbol according to the extraction temperature in the sulfuric acid, ie $\mathrm{LCA}_{1(80-2)}$ for $80^{\circ} \mathrm{C}$ and $\left.\mathrm{LCA}_{1(100-2)}\right)$ at $100^{\circ} \mathrm{C}$. LCA was dried in the oven at the temperature of $105^{\circ} \mathrm{C}$ for \pm 24 hours and allowed to dry in a desicator for \pm 6 hours. LCA is ready used as andsorbent for peat water after coagulation. The chemical composition of 
natural clay and adsorbent is determined by X-Ray Diffraction (XRD) Pan Analytical type Empyrean.

\subsection{Coagulation-floculation process of peat water}

Liquid coagulant $\left(\mathrm{LC}_{1(80-2)}, \mathrm{LC}_{1(100-2)}\right)$ and peat water sample were contacted with ratio 1:10 $(\mathrm{v} / \mathrm{v})$ in a beaker glass. The beaker was agitated by magnetic stirrer at various mixing time with speed $(160 \mathrm{rpm})$ for 2 minutes and slow mixing $(40 \mathrm{rpm})$ for 10 minutes. After agitation stop, the suspension was allowed to settle undisturbed for 6 hours. A sample was withdrawn using a pipette from the top inch of supernatant to detect the change of $\mathrm{pH}$, color, odor, TSS, TDS, and organic substance. The result of the analysis was compared to PERMENKES No.146/MEN/KES/PER/IX/1990 “about the Water Quality Requirements."

\subsection{Adsorption of peat water post-coagulation process}

Minor product extraction of natural clay $\left(\mathrm{LCA}_{1(80-2),} \mathrm{LCA}_{1(100-2)}\right)$ and peat water after coagulation were mixed with a variable ratio of $0.5: 100$ and $1: 100(\mathrm{w} / \mathrm{v})$. It was stirred evenly for 1 minute and allowed to stand for 24 hours. The supernatant was analyzed having same analysis parameters of the coagulation-flocculation process.

\section{Results and discussion}

\subsection{Characterization of liquid coagulant}

The various temperature effect of natural clay extraction was investigated. Cation concentration of liquid coagulant is represented in Table 1.

Table 1. Cation concentration $(\mathrm{mg} / \mathrm{L})$ and $\mathrm{pH}$ of liquid coagulant.

\begin{tabular}{|c|c|c|}
\hline Cation & $\mathbf{L C}_{\mathbf{1}(\mathbf{8 0}-\mathbf{2})}$ & $\mathbf{L C}_{\mathbf{1}(\mathbf{1 0 0}-\mathbf{2})}$ \\
\hline $\mathrm{Al}^{3+}$ & 1.22 & 1.25 \\
\hline $\mathrm{Fe}^{3+}$ & 0.24 & 0.22 \\
\hline $\mathrm{Na}^{+}$ & 5.10 & 7.91 \\
\hline $\mathrm{K}^{+}$ & 16.10 & 21.59 \\
\hline $\mathrm{Ca}^{2+}$ & 558.06 & 539.41 \\
\hline $\mathrm{Mg}^{2+}$ & 79.82 & 53.11 \\
\hline $\mathrm{pH}$ & 8.0 & 7.4 \\
\hline
\end{tabular}

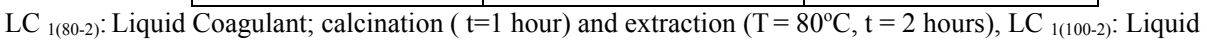
Coagulant; calcination ( $\mathrm{t}=1$ hour) and extraction $\left(\mathrm{T}=100^{\circ} \mathrm{C}, \mathrm{t}=2\right.$ hours)

Based on Table 1, mono and divalent cation were extracted more than trivalent by $\mathrm{H}_{2} \mathrm{SO}_{4}$ in both coagulants. Alkaline and alkaline earth metal are elements which have standard reduction potential more positive than trivalent cation ( $\mathrm{Al}$ and $\mathrm{Fe}$ ), means mono and divalent cation will be more reactive than trivalent. Therefore both coagulants have provided a slightly alkaline, namely $\mathrm{pH} 7.4$ for $\mathrm{LC}_{1(100-2)}$ and 8 for $\mathrm{LC}_{1(80-2)}$. The first coagulant has slightly less alkaline because the solvent is more evaporated at a higher 
temperature $\left(100^{\circ} \mathrm{C}\right)$. The results that are not much different were also found in liquid coagulants of LC3 $3_{(80-2)}$ and LC3 $3_{(100-2)}[14]$.

\subsection{Liquid coagulant performance for peat water}

The first step to improve the quality of peat water was through a coagulation process using liquid coagulant extracted from natural clay in sulfuric acid. The cations of clay, such as $\mathrm{Na}^{+}, \mathrm{K}^{+}, \mathrm{Ca}^{2+}, \mathrm{Mg}^{2+}, \mathrm{Al}^{3+}$, and $\mathrm{Fe}^{3+}$ have been extracted by sulfuric acid to form sulfate salts, and the salts can be ionized in water to mono, bi, and trivalent cations. All of these cations can act as coagulants, but the trivalent $\left(\mathrm{Al}^{+}\right.$and $\left.\mathrm{Fe}^{+}\right)$cations have the highest affinity in the coagulation process, following the rules of Schulze and Hardy. The trivalent cations have the lowest critical coagulation concentration among other cations, monovalent and bivalent, making them the most efficient in destabilizing colloidal particles $[15,16]$. Coagulation occurs in acidic conditions, due to the density of cation in the coagulant is quite high that the charge neutralization and complex reaction between coagulant species and colloidal particles was dominated by the coagulation mechanism [17].

In this regard, poor coagulation process has occurred. It probably because of $\mathrm{Al}$ and $\mathrm{Fe}$ in the liquid coagulant ( $\mathrm{pH} 7-8$ ) does not redissolve, because in accordance [18] that at $\mathrm{pH}$ 4.5-8 both of these cations are as a precipitated hydroxide of aluminum and ferric. Another reason that $\mathrm{Al}$ and $\mathrm{Fe}$ at $\mathrm{pH}>6$ form a negatively charged complex, $\mathrm{Al}(\mathrm{OH})_{4-}$ and $\mathrm{Fe}(\mathrm{OH})_{4-}$ [19]. The both were affected the coagulation process.

Table 2. Characteristic of peat water before and after coagulation treatment.

\begin{tabular}{|c|c|c|c|c|}
\hline \multirow{2}{*}{ Parameters } & \multirow{2}{*}{$\begin{array}{c}\text { Pre- } \\
\text { treatment }\end{array}$} & \multicolumn{2}{|c|}{ Coagulation treatment } & \multirow{2}{*}{$\begin{array}{c}\text { Permenkes No. } \\
\text { 416/Menkes/PER/IV } \\
\text { /1990 }\end{array}$} \\
\hline & & $\mathrm{LC}_{1(80-2)}$ & $\mathrm{LC}_{1(100-2)}$ & \\
\hline Color, TCU & 6170 & 5400 & 5780 & 50 \\
\hline Odor & Odorless & Odorless & Odorless & Odorless \\
\hline $\mathrm{pH}$ & 4.9 & 4.9 & 4.6 & $6.5-9$ \\
\hline Turbidity, NTU & 108 & 89 & 93.7 & 25 \\
\hline $\mathrm{TDS}, \mathrm{mg} / \mathrm{L}$ & 432 & 387 & 366 & no data \\
\hline $\mathrm{TSS}, \mathrm{mg} / \mathrm{L}$ & 176 & 65.5 & 69 & 1500 \\
\hline Organic substances, $\mathrm{mg} / \mathrm{L}$ & 355.07 & 346.02 & 334.04 & 10 \\
\hline
\end{tabular}

Peat water which coagulated by two kinds of coagulant experienced insignificant improvement (represent in Table 2). As a result, it was found that based on the color, $\mathrm{pH}$, turbidity, TSS, and organic substance is not feasible to be used as a source of clean water. According to Fig. 1, the highest removal efficiency for color, turbidity, and TSS was achieved by $\mathrm{LC}_{1(80-2)}$. It probably because of bivalent cations concentration are higher than the other coagulant (Table 1). Bivalent cations have the role as a coagulant, even though its effectivity is lower than the trivalent cations. On the other hand, $\mathrm{pH}$ value of 8 is the best condition to precipitate of $\mathrm{Fe}$ and $\mathrm{Al}$.

The comparison of the result with previous research $[5,14]$ is represented in Table 3. This is purposed to know the effectivity of liquid coagulant. $\mathrm{K}_{100-2}$ achieves the highest 
removal efficiency percentage. It was probably happened due to the cation $\mathrm{Al}$, and $\mathrm{Fe}$ concentration of each coagulant is different significantly.

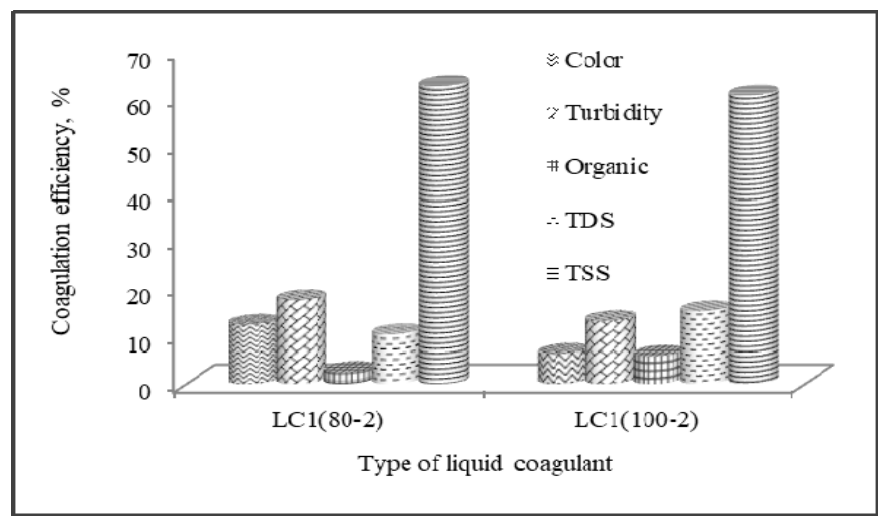

Fig. 1. Efficiency of coagulation process of peat water by two liquid coagulants.

The cation of $\mathrm{Al}$ and $\mathrm{Fe}$ concentration in $\mathrm{K}_{(100-2)}$ are $6.923 \mathrm{mg} / \mathrm{L}$ and $4.235 \mathrm{mg} / \mathrm{L}$, compared to this research $\mathrm{LC}_{1(80-2)}$ contained $1.22 \mathrm{mg} / \mathrm{L}$ of $\mathrm{Al}$ and $0.24 \mathrm{mg} / \mathrm{L}$ of $\mathrm{Fe}$, while there are $0.59 \mathrm{mg} / \mathrm{L}$ of $\mathrm{Al}$ and $0.08 \mathrm{mg} / \mathrm{L}$ of $\mathrm{Fe}$ in the $\mathrm{LC}_{3(80-2)}$ of liquid coagulants, respectively. Based on Schulze Hardy rule, the power destabilization colloidal particles is influenced by the greater valency of the opposite charge ion of colloidal particle surface (counter ion). The greater valency of cation, the CCC will be smaller $[15,16]$. Hence the colloidal particles will be coagulated effectively. However, in this research, mono and bivalent cations concentration of $\mathrm{LCl}_{(80-2)}$ is higher than trivalent cations. So, the performance of $\mathrm{LC}_{1(80-2)}$ was occurred ineffective on peat water treatment.

Table 3. Comparison of liquid coagulant performance.

\begin{tabular}{|c|c|c|c|}
\hline \multirow{2}{*}{ Parameters } & \multicolumn{3}{|c|}{ Coagulation efficiency, \% } \\
\cline { 2 - 4 } & $\mathbf{L C}_{\mathbf{1 ( 8 0 - 2 )}}$ & $\mathbf{K}_{\mathbf{( 1 0 0 - 2 )}}[\mathbf{5}]$ & $\mathbf{L C}_{\mathbf{3 ( \mathbf { ( 8 0 } - \mathbf { 2 }} \mathbf{[ 1 4}]}$ \\
\hline Color & 12.50 & 56.90 & 13.6 \\
\hline Turbidity & 17.59 & 84.61 & 13.5 \\
\hline TDS & 10.41 & 85.74 & - \\
\hline TSS & 62.78 & 96.80 & - \\
\hline Organic substance & 2.55 & 82.51 & 6.5 \\
\hline
\end{tabular}

The main factor that caused differences between $\mathrm{Al}$ and Fe cations which extracted in liquid coagulant is the clay as a precursor on synthesized liquid coagulant. The clay is a local natural resource which has heterogenous mineral distribution. It might cause differences amount of extracted cation concentration, although the condition was the same.

\subsection{Adsorbent performance of peat water post-coagulation}

According to Fig. 2, the decreasing efficiency of colloidal particles is influenced by the byproduct adsorbent of liquid coagulant (LCA), it was found of about $96 \%$ color, $98 \%$ 
turbidity, $82 \%$ organic substance respectively, and $\mathrm{pH} 7.5$. It probably because clay activated by $\mathrm{H}_{2} \mathrm{SO}_{4}$ has high cation exchange capacity. Proton $\mathrm{H}^{+}$at the surface of LCA has a role as an active adsorption site.

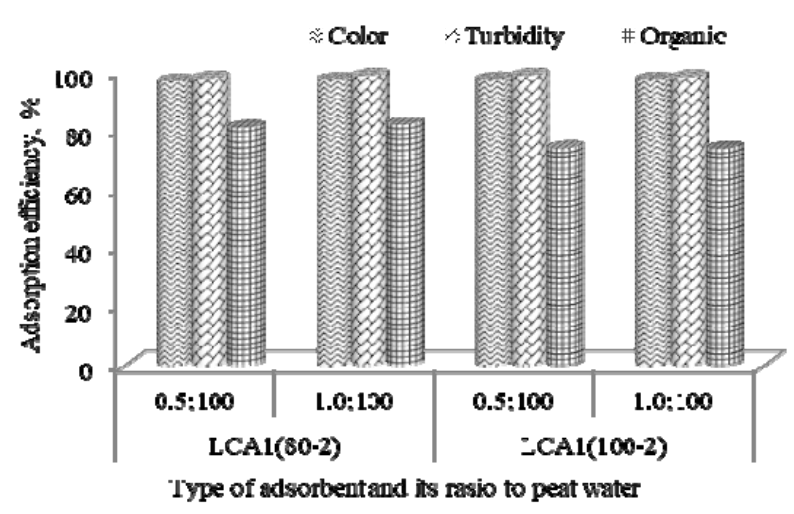

Fig. 2. Adsorbent performance after coagulation process.

The appearance of the color of peat water has been proved caused by anionic molecules including humic and fulvic acid. The molecules are hydrophilic colloidal that produce of dissociation of carboxyl and phenolic functional groups [20]. This negative charge has been neutralized by cation at the surface of the clay. The dosage effect of adsorbent on adsorption of peat water after coagulation was shown in Fig. 2. From the figure, it was observed that the percentage removal of colloidal substance slightly increased on increasing the adsorbent dose from 0.5 to $1 \mathrm{~g}$. This is due to the excessive availability of exchangeable sites or the occurrence of interfacial interaction between adsorbent and adsorbate [6].

\subsection{Characterization of calcined and extracted clay}

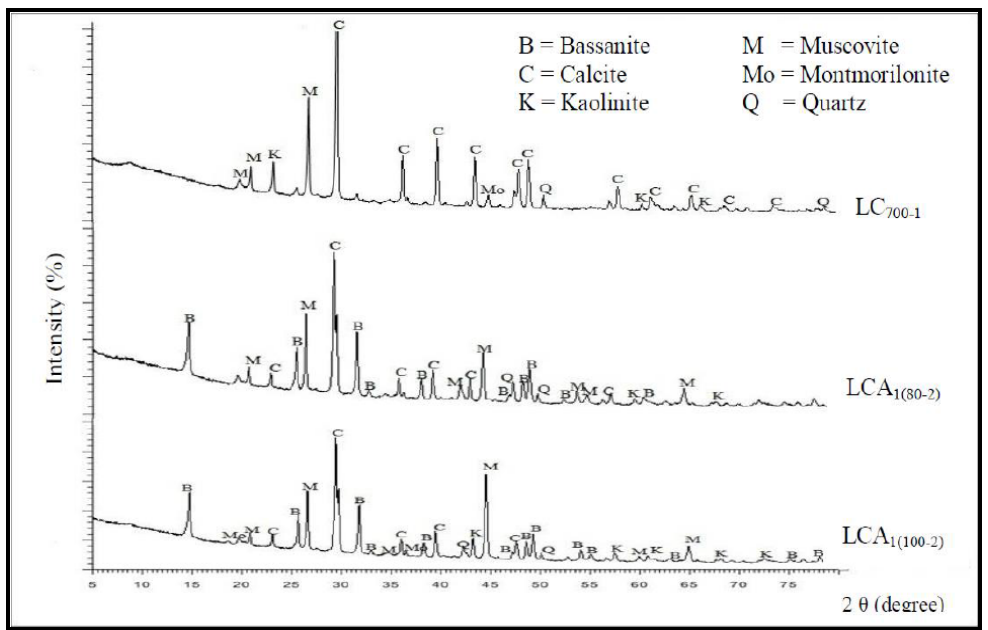

Note: $\mathrm{LC}_{700-1}=$ Calcined Cengar Clay at temperature $700^{\circ} \mathrm{C}$ for 1 hour, $\mathrm{LCA}_{1(80-2)}=$ Byproduct adsorbent of liquid coagulant; calcination ( $\mathrm{t}=1$ hour) and extraction $\left(\mathrm{T}=80^{\circ} \mathrm{C}, \mathrm{t}=2\right.$ hours), $\mathrm{LCA}_{1(100-2)}=$ Byproduct adsorbent of liquid coagulant; calcination $(\mathrm{t}=1$ hour $)$ and extraction $\left(\mathrm{T}=100^{\circ} \mathrm{C}, \mathrm{t}=2\right.$ hours).

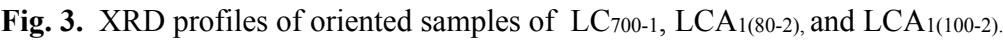


The residue of liquid coagulant is applied as an adsorbent for peat water after the coagulation process. The adsorbent was characterized by X-Ray Diffraction to determine the mineral composition. The XRD pattern is given in Fig. 3 which showed that the clay was mainly composed of montmorillonite, muscovite, kaolinite, quartz, and calcite respectively. Even though, there was another mineral (bassanite $\mathrm{CaSO}_{4} \cdot 2 \mathrm{H}_{2} \mathrm{O}$ ) was found in LCA. It was probably due to an effect of clay activated by $\mathrm{H}_{2} \mathrm{SO}_{4}$ which is involved of sulfate ion ( $\left.\mathrm{SO}_{4} 2-\right)$ and led to the surface interlayer of clay that contains calcium, and then can produce bassanite.

Calcined clay at temperature $600-700^{\circ} \mathrm{C}$ has been found to change to gamma alumina phase perfectly [21]. Gamma alumina is a phase which can dissolve in acidic and alkaline condition, and as a result, $\mathrm{Al}$ in calcined clay will be extracted easily [22]. As a fact to this experiment, $\mathrm{Al}$ and $\mathrm{Fe}$ extracted in coagulant was obtained poor. Fig. 2 showed that the clay as a precursor of liquid coagulant composed of mineral non-clay (calcite) dominantly. So, liquid coagulant contained amount of $\mathrm{Al}$ and Fe cations has lower than other cations.

\subsection{Coagulation-adsorption performance on peat water treatment}

In Table 4, the best coagulation-adsorption performance was achieved in the pair of $\mathrm{LC}_{1(80-}$ ${ }_{2)}-\mathrm{LCA}_{1(80-2)}$ with 1:100 (w/v) ratio of adsorbent: peat water. According to Fig. 3, that montmorillonite mineral was contained in $\mathrm{LCA}_{1(80-2)}$ by $18.66^{\circ}$ and $37.30^{\circ}$.

Table 4. Coagulation-adsorption performance on peat water treatment.

\begin{tabular}{|c|c|c|c|c|}
\hline \multirow{3}{*}{ Parameters } & \multicolumn{4}{|c|}{ Coagulation-adsorption treatment } \\
\hline & \multicolumn{2}{|c|}{$\operatorname{LC}_{1(80-2)}-\operatorname{LCA}_{1(80-2)}$} & \multicolumn{2}{|c|}{$\operatorname{LC}_{1(100-2)}-\operatorname{LCA}_{1(100-2)}$} \\
\hline & $0.5: 100(w / v)^{@}$ & $1: 100(w / v)^{@}$ & $0.5: 100(w / v)^{@}$ & $1: 100(\mathbf{w} / \mathbf{v})^{a}$ \\
\hline Color, TCU & 209 & 185 & 186 & 188 \\
\hline Odor & Odorless* & Odorless * & Odorless * & Odorless * \\
\hline $\mathrm{pH}$ & $7.5^{*}$ & $7.5^{*}$ & $7.7^{*}$ & $7.6^{*}$ \\
\hline Turbidity, NTU & $2.52 *$ & $1.75^{*}$ & $1.78 *$ & $2.33^{*}$ \\
\hline Organic Substance, $\mathrm{mgL}^{-1}$ & 67.62 & 63.83 & 88.48 & 89.11 \\
\hline
\end{tabular}

${ }^{\circledR}$ : ratio of adsorben (LCA) : peat water, *: fulfilled Permenkes No.416/ Menkes/PER/IV/1990.

There are many types of clay, but montmorillonite clays are to have highest sorptive capacity in comparison to the other. Montmorillonite is recognized as an excellent adsorbent owing to the existence of active sites such as the surface and ion-exchange sites [23]. So, the decreasing parameter efficiency of color and turbidity by $\mathrm{LCA}_{1(80-2)}$ is higher than another. The table was also shown that three water parameters of odor, $\mathrm{pH}$, and turbidity had met Permenkes No.416/Menkes/PER/IV/1990 after being absorbed by the four adsorbents on both the adsorbent-peat water $(\mathrm{w} / \mathrm{v})$ ratio.

\section{Conclusions}

Synthesized liquid coagulant proved that have $\mathrm{pH}$ about 7.4-8 and cation concentration $\mathrm{Al}$ $1.22-1.25 \mathrm{mg} / \mathrm{L}, \mathrm{Fe} 0.22-0.24 \mathrm{mg} / \mathrm{L}$ respectively. The liquid coagulant was ineffective to improve peat water quality. The adsorbent of $\mathrm{LCA}_{1(80-2)}$ of a byproduct of liquid coagulant 
on $1: 100(\mathrm{w} / \mathrm{v})$ ratio was improved the parameters of peat water, by removing as much as the color $96.57 \%$, turbidity $98.03 \%$, organic substances $81.55 \%$ and $\mathrm{pH} 7.5$ respectively. So does combine of $\mathrm{LC}_{1(80-2)}$ and $\mathrm{LCA}_{1(80-2)}$ being the most effective pair of liquid coagulantadsorbent on reduces the measured parameters. The adsorbent performance is much better than the liquid coagulant in the peat water treatment.

\section{References}

1. Dept of Economic and Social Affairs/Population Division, World population prospect: the 2010 revision, Volume I. Comprehensive tables (United Nations, New York, 2011)

2. M. Hajjaji, Y. Mountassir, A. Benyaich, Appl Water Science 6, 1 (2014)

3. M. Ajbary, A. Santos, V. Morales-Flórez, L. Esquivias, Appl. Clay Sci. 80-81 (2013)

4. Muhdarina, Pencirian lempung cengar asli dan berpilar serta sifat penjerapannya terhadap logam berat (Universiti Kebangsaan Malaysia, Selangor, 2011)

5. Muhdarina, A. Linggawati, T.A. Amri, R. Syahroni, H. Sutrisno, Prosiding Seminar Nasional MIPA 2014 (2014)

6. I. Ali, M. Asim, T. A. Khan, J. Env. Man. 113 (2012)

7. A.A. Al-Zahrani, M.H.A. Majid, JKAU Eng. Sci. 20, 2 (2009)

8. Elma, Efektifitas tanah lempung sebagai koagulan dalam memperbaiki kualitas fisik dan kimia air gambut di Desa Blonkut Kecamatan Merbau Kabupaten Labuhanbatu (Universitas Sumatera Utara, Medan, 2006)

9. M. Awad, F. Li, W. Hongtao, IJRS 15, 2 (2012)

10. Muhdarina, S. Bahri, Nurhayati, T.A. Amri, A. Hamid, Pros. Semirata FMIPA Universitas Lampung (2013)

11. R.M. Diana, S. Notodarmojo, Studi awal pemanfaatan lempung peminggir sebagai koagulan cair (ITB, Bandung, 2010)

12. A. Sdiri, M. Khairy, S. Bouaziz, S. El-Safty, Appl. Clay Sci. 126 (2016)

13. S. Bentahar, A. Dbik, M.E. Khomri, N.E. Messaoudi, A. Lacherai, Groundwater for Sustainable Devp. 6 (2018)

14. Muhdarina, S. Bahri, A. Linggawati, P.H. Yanti, N. Anggraini, S. Nopiyani. Prosiding Seminar Nasional Kimia-Lombok 2016 (2016)

15. W. Nowicki, G. Nowicka, J. of Chemical Edu. 71, 7 (1994)

16. S. Kaufhold, A. Kaufhold, R. Dohrmann. Colloids and Interfaces 2, 1 (2018)

17. C.B. Chuan, G.B. Yu, X.C. Hua, F. Ying, L. Xin, Chinese Sci. Bull. 55, 14 (2010)

18. R.S. Wardani, B. Iswanto, Winarni, Jurnal Teknologi Lingkungan 5, 2 (2009)

19. Muhdarina, Nurhayati, S. Bahri, T.A. Amri, A. Linggawati, Yulianti, Akta Kimindo 3, 1 (2018)

20. Z.L. Yang, B.Y. Gao, Q.Y. Yue, Y. Wang, J. of Hazardous Mat. 178 (2010)

21. V. Rotua, JOM FMIPA 2, 1 (2015)

22. T. Pandiangan, Prosiding PPI-PDIPTN (2006)

23. J. E. Brady, General chemistry; principle and structure (Bina Rupa Aksara, Jakarta, 1999)

24. P. Suarya, Jurnal Kimia 6, 1 (2012) 